\title{
Original article \\ Monitoring muscle damage markers during a four-week downhill walking exercise program
}

\author{
Leonardo Coelho Rabello de Lima \\ Thiago Pires de Oliveira \\ Felipe Bruno Dias de Oliveira \\ Claudio de Oliveira Assumpção \\ Camila Coelho Greco \\ Benedito Sérgio Denadai \\ São Paulo State University at Rio Claro, Brazil
}

\begin{abstract}
Eccentric-based exercise is known to induce muscle damage (MD). The purpose of this study was to investigate effect of downhill walking (DW) sessions on MD and aerobic markers in young adults. Eight male subjects were submitted to a 4-week DW periodized exercise program. Subjects' soreness (SOR) was assessed each training day. Serum creatine quinase activity (CK) was collected before the first training session, and at the end of each of the four weeks. Oxygen uptake $\left(\mathrm{VO}_{2}\right)$ and perceived exertion (PE) were assessed during the last training session every week. Increases in SOR were found only at the third and fourth training days. Increased CK concentration was found at the third training week. No significant increases in VO2 and PE were found throughout the program. We concluded that DW sessions elicit significant MD, but not enough to impair it in further sessions. Therefore, DW can be used as a training protocol following proper periodization.
\end{abstract}

Keywords: downhill walking, muscle damage, training

Resumo- "Monitoramento de marcadores de dano muscular durante um programa de quatro semanas de treinamento de caminhada em declive." Exercícios excêntricos costumam induzir dano muscular (DM). O objetivo deste estudo foi investigar respostas aeróbias e de DM a sessões de caminhada em declive (CaED) em adultos. Oito voluntários realizaram um programa periodizado de treinamento de CaED. A dor muscular (DMIT) foi coletada durante todos os dias de treinamento. A atividade sérica de creatina quinase (CK) foi coletada antes da primeira sessão e ao final das semanas 1-4. O consumo de oxigênio $\left(\mathrm{VO}_{2}\right)$ e a percepção de esforço (PE) foram coletados durante a última sessão de treinamento de cada semana. Aumentos na DMIT foram identificados no terceiro e quarto dias de treinamento. Os valores de CK se apresentaram aumentados na terceira semana. Não foram identificadas diferenças nos valores obtidos de VO2 e PE. Concluímos que sessões de CaED induzem DM, porém este não afeta sessões posteriores. Portanto, a CaED pode ser utilizada como um método de treinamento, possibilitando sua periodização.

Palavras-chaves: caminhada em declive, dano muscular, treinamento

Resumen- "Marcadores de monitoreo de daño muscular durante un programa de cuatro semanas de entrenamiento a pie cuesta abajo." Ejercicio excéntrico desacostumbrado es conocido por inducir daño muscular (DM). El objetivo de este estudio fue investigar las respuestas a sesiones de caminar cuesta abajo (DW) en los adultos jóvenes, la evaluación de MD y los marcadores de aeróbicos. Ocho sujetos varones fueron sometidos a un programa de ejercicios de periodización de DW de 4 semanas. El dolor de los sujetos (SOR) se evaluó todos los días de entrenamiento. Actividad de la creatina quinasa sérica (CK) se recogió antes de la primera sesión de entrenamiento, y al final de las semanas 1-4. El consumo de oxígeno $\left(\mathrm{VO}_{2}\right)$ y la percepción subjetiva del esfuerzo (PE) se evaluaron durante la última sesión de entrenamiento cada semana. Los aumentos en SOR se encontraron sólo en los tercero y cuarto día de entrenamiento. El aumento de la concentración de CK se encuentra en la tercera semana de entrenamiento. No hay un aumento significativo en el VO2 y PE se encuentran en todo el programa. Llegamos a la conclusión de que las sesiones DW provocan MD significativo, pero no lo suficiente como para poner en peligro otras sesiones. Por lo tanto, DW puede ser adoptado como método de entrenamiento, permitiendo periodización adecuada.

Palabras claves: descenso a pie, daño muscular, entrenamiento 


\section{Introduction}

It is well established that unaccustomed exercise can lead to exercise-induced muscle damage (EIMD), especially when eccentric actions are performed at high volumes or intensities (Brenner et al., 1999; Lindstedt, LaStayo, \& Reich, 2001; Clarkson \& Hubal, 2002; Yu, Malm, \& Thornell, 2002). Downhill running (DR), an exercise model frequently used to generate muscle damage (Byrnes et al., 1985), seems to induce EIMD by two associated mechanisms: high intensity (due to the declined surface) and high volume (due to the cyclic characteristic of running) of eccentric contractions. Indeed, several studies have demonstrated that DR can lead to strength loss, delayed-onset muscle soreness (DOMS), changes in running kinematic parameters and impairment of running economy (Chen et al., 2007; Chen, Nosaka, Lin, Chen, \& Wu, 2009; Assumpção et al., 2013). Therefore, DR can be considered a highly damaging activity, which would impair further sessions if applied as training stimulus.

A considerable number of studies have also investigated the effect of downhill walking (DW) on biomechanical and physiological responses. However, the majority of them did not take EIMD in consideration, assessing only biomechanical (joint kinematics, and muscle activity) (Holm, Contakos, Lee, \& Jang, 2010; Hunter, Hendrix, \& Dean, 2010) or cardiorespiratory intensity-related factors (oxygen uptake) (Abe et al., 2011; Minetti, Moia, Roi, Susta, \& Ferretti, 2002). Evidence obtained from animal experimental models has shown that the DW training can lead to neuromuscular (Lyn \& Morgan, 1994) and metabolic (Hahn et al., 2007) adaptations. In humans, few studies have analyzed the chronic effects of DW training on physical fitness. Yang, Lee, Cheng and Wang (2010) verified that four weeks of DW ( -3 to $-8.5 \%$ slope) training (30 minutes, at 0.63 to $0.99 \mathrm{~km} / \mathrm{h}, 3$ days per week,) was more effective than conventional therapy in improving muscle strength and gait performance in individuals with Parkinson's disease. Gault, Clements, and Willems (2012) investigated the effects of 12 weeks of DW (-10\% slope) training (30 minutes at 53 to $81 \%$ of the maximal walking speed, 3 days per week) in older adults. Although there was significant improvement in functional tests, the isokinetic strength of the knee extensors and flexors remained unaltered after the training period. In these studies, EIMD markers were not controlled. Since the exercise intensity (speed and slope) and the weekly frequency were relatively low, it is possible that the muscle damage response may have been small, allowing the volunteers to accomplish the whole training protocol.

To our knowledge, no studies have investigated the effects of DW training in individuals with higher fitness levels (i.e., aerobic and strength) than those individuals in the studies mentioned earlier (Yang et al., 2010; Gault et al., 2012). Since adaptation to training is dependent on the stress levels induced by the exercise, it is possible to hypothesize that, in active healthy young adults, the training load (intensity, volume and frequency) must be higher than that utilized in the studies conducted by Yang et al. (2010) and Gault et al. (2012). However, there are no studies showing the possibility of using higher loads (intensity, volume and frequency) with DW training, which could allow neuromuscular and metabolic adaptation in young adults.

Therefore, the aim of our study was to examine changes in EIMD symptoms during a four-week DW training in healthy young adults. Based on the data obtained by Kamandulis et al. (2011), it was hypothesized that DW training with progressively increasing load can be performed by healthy young adults without eliciting enough EIMD that would impair subsequent training sessions.

\section{Methods}

\section{Participants}

Eight healthy male active young adults took part in the present study. The volunteers were physical education students (undergraduate and graduate) involved in recreational sports (soccer, basketball, and volleyball) who had no history of participation in regular resistance and/or aerobic training for at least 6 months prior to the beginning of this study. They were instructed not to engage in any unusual physical activities, to keep their regular diet pattern, and to drink plenty of water during the experimental period. Before engaging in any experimental procedures, they were informed about procedure and ethical details, read and signed an informed consent. The study's protocol was previously approved by São Paulo State University's Ethics Committee (Protocol number: 3310/2011).

\section{Experimental design}

Before engaging in the exercise program, volunteers had their maximal oxygen uptake $\left(\mathrm{VO}_{2 \max }\right)$ determined. All volunteers underwent 28 DW training sessions distributed throughout a four-week period, with 7 sessions per week. Volunteers received training sessions from Monday to Friday. Thus, they practiced twice on Tuesdays and Thursdays. Each training session consisted of a 20 minutes DW in a treadmill (Pulsar - h/p/ cosmos - Nussdorf, Germany) with inclination set at $-16 \%$. The walking speed was set at $5 \mathrm{~km} / \mathrm{h}$ in the first session and, at the beginning of each week, $0.5 \mathrm{~km} / \mathrm{h}$ increments were applied in the walking speed. Perceived SOR was collected every day before the training session in order to identify the manifestation of DOMS. CK activity was determined at 5 distinct moments during the study in order to investigate the muscle damage magnitude induced by the DW sessions: before the first session and at the end of each training week. The cardiorespiratory responses to the DW sessions were also assessed at the last training session every week by measuring oxygen uptake $\left(\mathrm{VO}_{2}\right)$ and by registering their perceived exertion (PE) parameter. 


\section{Maximal oxygen uptake}

The $\mathrm{VO}_{2 \max }$ was assessed via a treadmill incremental test. Treadmill inclination was set at $1 \%$ and, at the beginning of the test, volunteers ran for 3 minutes at $7 \mathrm{~km} / \mathrm{h}$, in order to warm up. After the third minute, treadmill speed was increased by $0.2 \mathrm{~km} / \mathrm{h}$ every $12 \mathrm{~s}$. Volunteers were advised to sustain the activity until exhaustion. Throughout the tests, respiratory and pulmonary gas-exchange variables were measured using a breath-by-breath gas analyzer (Quark PFTergo, Cosmed, Italy). Before each test, the oxygen and carbon dioxide analysis systems and pneumotachograph were calibrated using precision reference gases and a syringe of known volume (3 1), respectively, according to the manufacturer's instructions. The $\mathrm{VO}_{2 \max }$ was defined as the highest average 15-s $\mathrm{VO}_{2}$ value recorded during the incremental test.

\section{Perceived muscle soreness}

SOR was assessed in the volunteers' dominant legs. The measurement was made using a visual analog scale (VAS) consisting of a $100 \mathrm{~mm}$ line with the writings "not sore at all" at one end $(0 \mathrm{~mm})$ and "very, very sore" at the other $(100 \mathrm{~mm})$. Volunteers were instructed to rate their perceived soreness on the VAS after climbing up and down from a $45 \mathrm{~cm}$ bench.

\section{Creatine kinase (CK) assessment}

A $500 \mu 1$ sample of arterialized venous blood was drawn from the volunteers' earlobe and centrifuged for 10 minutes at $5600 \mathrm{rpm}$ in a commercial centrifuge (Microhemato Model 2410, Fanem, São Paulo, Brazil) to obtain blood plasma. The plasma samples were stored at $-10^{\circ} \mathrm{C}$ before being analyzed for serum $\mathrm{CK}$ activity determined spectrophotometrically (Bio-2000, Bioplus, São Paulo, Brasil) using a test kit (CK-NAC UV, Wiener Lab., Rosário, Argentina). The normal reference ranges for male adults using this method are 24-195 IU.1-1.

\section{Oxygen uptake and perceived exertion}

The $\mathrm{VO}_{2}$ was assessed at the end of each training week. While the volunteers performed the training session, their exhaled gases were collected by using the same gas analysis system for $\mathrm{VO}_{2 \max }$ assessment. The mean of the $\mathrm{VO}_{2}$ value obtained from the $5^{\text {th }}$ to the $20^{\text {th }}$ minute of each training session was used for further analysis. Perceived exertion was also assessed at each week's final session. Volunteers were instructed to classify their perceived exertion according to the Borg's 6-20 scale (Borg, 1982) at the end of the training session. The reported values were registered and used for further analysis.

\section{Statistical analysis}

Data normality was tested via the Shapiro-Wilk test. Changes in $\mathrm{VO}_{2}$ and $\mathrm{PE}$ over time were assessed through one-way analysis of variance (ANOVA), followed by Bonferroni's post-hoc test when appropriate. Friedman's and Wilcoxon's non-parametric tests were used for comparison of $\mathrm{CK}$ and SOR, since these variables showed non-Gaussian distribution. Statistical significance levels were set as $p \leq 0.05$. All data were expressed as mean \pm standard deviation, unless otherwise stated.

\section{Results}

Anthropometric characteristics, $\mathrm{VO}_{2 \max }$ as well as baseline values for CKand SOR are shown in Table 1. Signifi-cant time effects (weeks of training) were found for $\mathrm{VO}_{2}, \mathrm{CK}$, and SOR while no significant time effect was found for PE.

The $\mathrm{VO}_{2}$ values presented small, but not significant changes over the weeks, even though significant time effect was found. The most elevated value for this marker was obtained at week $4(12.9 \pm 2.3 \mathrm{ml} . \mathrm{kg} .-1 \mathrm{~min}-1-28.9 \%$ VO2max), but was not statistically different from any other values (week $1=10.7 \pm 0.8 \mathrm{ml} . \mathrm{kg} .{ }^{-1} \mathrm{~min}^{-1}-23.9 \% \mathrm{VO}_{2 \max }$; week $2=10.7 \pm 1.4 \mathrm{ml} . \mathrm{kg} \cdot{ }^{-1} \mathrm{~min}^{-1}-23.9 \% \mathrm{VO}_{2 \max }$; week 3 $=12.2 \pm 2.3 \mathrm{ml} . \mathrm{kg} .{ }^{-1} \mathrm{~min}^{-1}-27.3 \% \mathrm{VO}_{2 \max }$ ) (Figure 1$)$.

PE values were also not significantly different over the four training weeks $(p>0.05)$. PE values for weeks $1-4$ were $10.4 \pm 3.1,9.6 \pm 2.9,10 \pm 3.2$ and $11.8 \pm 2.6$, respectively (Figure 2 ).

CK activity at weeks 1-4 was significantly different from baseline $(p=0.04)$. No significant differences were found between the values obtained at weeks 1,2 and $3(p>$ $0.05)$. In addition, the value of week 4 was significantly reduced when compared with the week 3 ( $p<0.05)$. CK activity is graphically represented in Figure 3.

Table 1. Anthropometric characteristics and baseline values of the indirect markers of muscle damage. BMI - Body mass index; $\mathrm{CK}=$ Creatine kinase $; \mathrm{SOR}=$ Soreness $; \mathrm{VO}_{2 \max }=$ Maximum oxygen uptake.

\begin{tabular}{lcccc}
\hline & Mean & SD & Minimum & Maximal \\
\hline Age (years) & 22.6 & 3.4 & 18 & 29 \\
Body mass (kg) & 80.3 & 19.94 & 60.5 & 123.8 \\
Stature (cm) & 173 & 9 & 1.62 & 1.88 \\
BMI (Kg.m $)$ & 26.3 & 4.4 & 21.4 & 35 \\
CK (U/l) & 64 & 104.4 & 32 & 267 \\
SOR (cm) & 0 & 0.1 & 0 & 0.2 \\
VO ${ }_{2}^{2}$ max $\left(\mathrm{ml}^{2} . \mathrm{kg}^{-1} \cdot \mathrm{min}^{-1}\right)$ & 44.6 & 3.4 & 37.4 & 48.7 \\
\hline
\end{tabular}




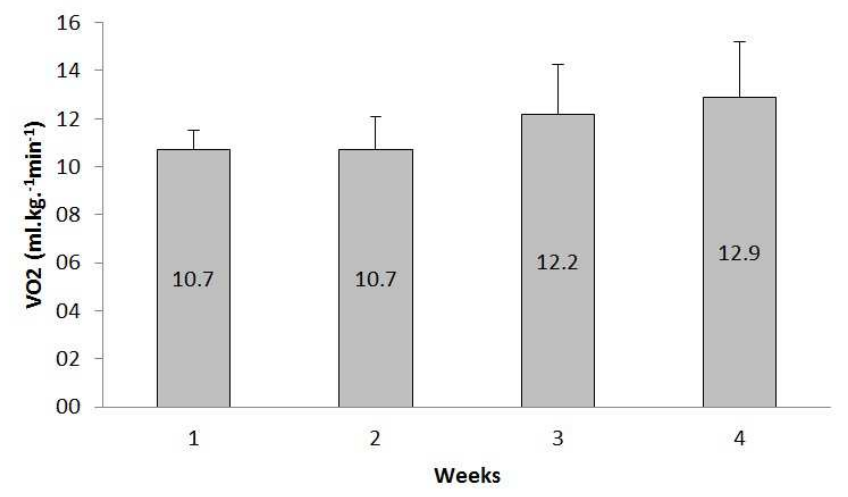

Figure 1. Oxygen uptake $\left(\mathrm{VO}_{2}\right)$ values obtained during the last training session of weeks 1-4. Data are represented by mean + SD.

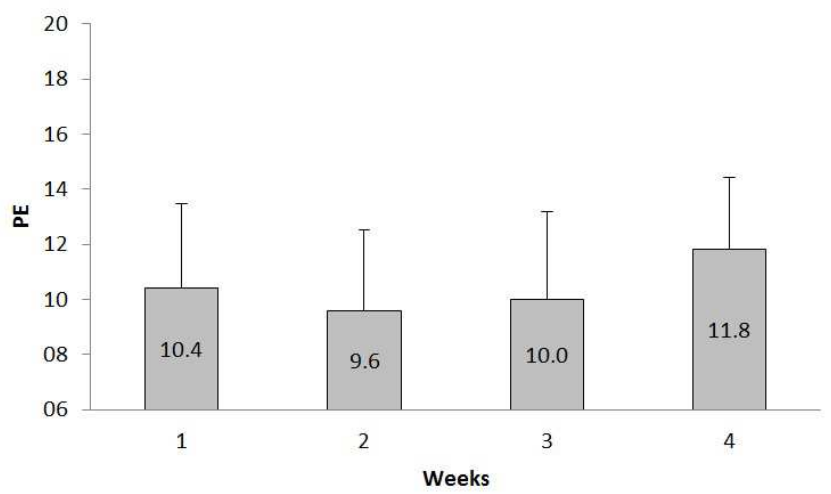

Figure 2. Perceived exertion (PE) values obtained during the last training session of weeks 1-4.

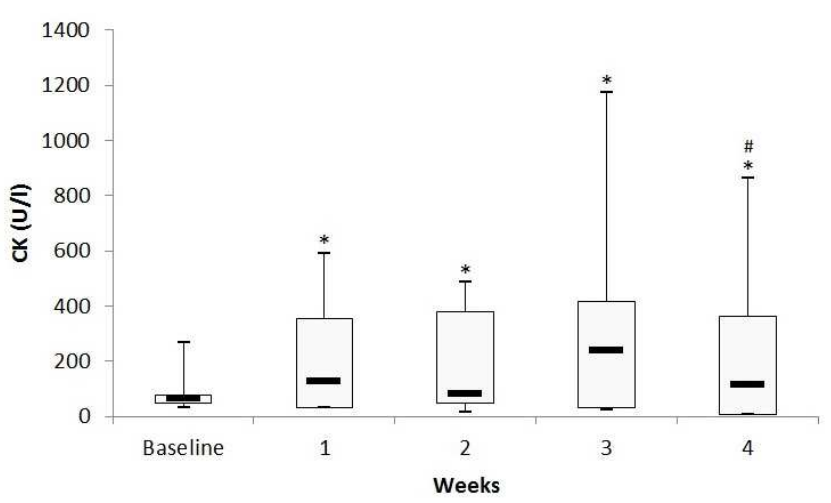

Figure 3. Creatine Kinase (CK) activity obtained at baseline and after the last training session of weeks $1-4 . * p<0.05$ compared to baseline value. \# $p<0.05$ compared to third week value.

Increased SOR values were found from the $2^{\text {nd }}$ to the $5^{\text {th }}$ day, when compared with the $1^{\text {st }}$ day of each training week $(p<0.05)$. Reduced values were found at the $4^{\text {th }}$ week, when compared to the $1^{\text {st }}$ week $(p<0.05)$ (Figure 4$)$.

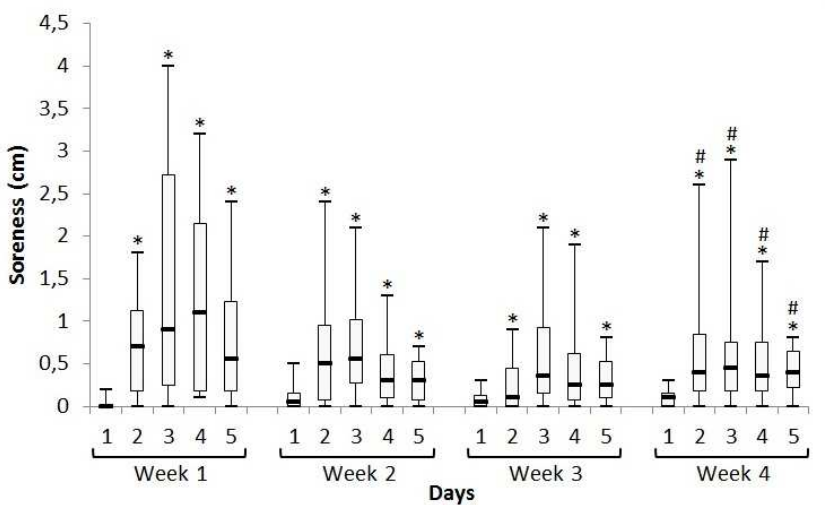

Figure 4. Soreness (SOR) values assessed every training day. $* p<$ 0.05 compared to the first training session of week one. \# $p<0.05$ compared to the same training session of the first week.

\section{Discussion}

The aim of our study was to examine changes in EIMD symptoms during a four-week DW training in healthy young adults. Our main finding was that the four-week DW training program with progressively increasing load produced moderate increase in indirect muscle damage markers in healthy young adults. However, consistent with previous research (Chen, Lin, Chen, Lin, \& Nosaka, 2011; Lima \& Denadai, 2011; Nosaka, Newton, Sacco, Chapman, \& Lavender, 2005), a repeated bout effect (i.e., reduced muscle damage) was found during the fourth training week.

Although progressive overload (i.e., increase in treadmill speed) was applied throughout the training weeks (increase of $0.5 \mathrm{~km} / \mathrm{h}$ per week), the $\mathrm{VO}_{2}$ values were not significantly different between the training weeks. Indeed, Entin, Gest, Trancik, and Coast (2010) found that the energetic cost was similar between 5 different walking speeds (varying from 2.8 to $6.4 \mathrm{~km} / \mathrm{h}$ ) during DW. Moreover, Hunter et al. (2010) found that cardiorespiratory intensity variations during DW associated to manipulation of the treadmill decline levels lead to stability adjustments, whereas propulsion is primarily conferred by gravity itself during this type of exercise. Therefore, we believe that, in order to promote proper overload to the cardiorespiratory system during DW training programs, treadmill inclination should be firstly considered, instead of walking speed.

In the study conducted by Gault et al. (2012), $\mathrm{VO}_{2}$ was not measured during the DW training program. However, there were significant increases in heart rate $(\sim 10 \%)$ and PE $(\sim 10 \%)$, due to the increase in the absolute exercise intensity (from $53 \%$ to $81 \%$ of the maximal walking speed). In our study, there was no significant change in PE between the training weeks. These different results may be explained, at least in part, by the different physical fitness levels of the participants in our study, when compared to older adults studied by Gault et al. (2012).

Although $\mathrm{VO}_{2}$ and $\mathrm{PE}$ did not change with training, $\mathrm{CK}$ 
activity was significantly increased during all training weeks when compared with baseline (Figure 3). Thus, muscle damage induced by DW seems to occur in lower intensity $\left(\sim 24 \% \mathrm{VO}_{2 \max }\right)$ and smaller weekly volume (100 min) than those suggested by ACSM (2000) guidelines on physical activity (i.e., 40-60\% $\mathrm{VO}_{2 \max }, 150 \mathrm{~min}$ ). However, CK activity obtained at the end of the fourth training week was significantly reduced when compared with the third week. This attenuated response could be attributed to partial protection conferred by the previous training weeks, i.e., repeated bout effect. Indeed, several studies have verified that the magnitude of changes on muscle damage markers might be attenuated after one (McHugh, 2003; Nosaka, Newton, Sacco, Chapman, \& Lavender, 2005; Chen, Lin, Chen, Lin, \& Nosaka, 2011; Lima \& Denadai, 2011) or a series (Kamandulis et al., 2011) of eccentric exercise sessions.

When compared with the $1^{\text {st }}$ day of the $1^{\text {st }}$ training week, SOR was significantly increased from the $2^{\text {nd }}$ to $5^{\text {th }}$ day. These elevated SOR levels could represent the DOMS resulting from the first training session, since it usually peaks at 24 to 48 hours after the damaging bout (Nosaka, Newton, \& Sacco, 2002; Braun \& Dutto, 2003; Foschini, Prestes, \& Charro, 2007). The increased SOR pattern presented at the first training week (1-5) was also observed in the following weeks (Figure 4). These increased SOR patterns during each training week seems to be determined by both the higher exercise intensity (i.e., $+0.5 \mathrm{~km} / \mathrm{h}$ per week) and the accumulated walking volume. However, similar to CK, the increase in SOR was attenuated during the fourth week, suggesting the existence of the repeated bout effect. It is important to note that the increase in SOR found during the DW training period is minimal when compared with those caused by severe EIMD (Jamurtas et al., 2005; Saka et al., 2009; Lima \& Denadai, 2011). Finally, SOR and CK responses were similar to those found by Kamandulis et al. (2011), using a three-week periodized drop-jump exercise program, which confirms that the DW protocol adopted in our study can be used as training stimulus without impairing the results in further sessions.

Finally, there are important limitations in this study. First, the number of subjects tested was relatively low, which may have led to a type II error. This limitation comes from the study design characteristics (i.e., longitudinal) utilized to test our research hypothesis. Second, other important indirect muscle damage markers (i.e., muscle strength) were not assessed during the training. However, Chen et al. (2013) have shown that just two maximal isometric voluntary contractions attenuated the magnitude of changes in the muscle damage markers induced by 30 maximal isokinetic eccentric contractions. Thus, we decided not to use peak torque measurements, since this could generate misinterpretations of our results.

\section{Conclusion}

A DW training program with progressively increasing load can lead to significant increases on EIMD markers. However, a repeated bout effect (i.e., reduced muscle damage) was found during the fourth week of training, suggesting that neuromuscular system can adapt in response to increased load of eccentric exercise. These data support the possibility of using DW adopted in our study as a training stimulus in order to study its effects on physical fitness of young adults.

\section{References}

Abe, D., Fukuoka, Y., Muraki, S., Yasukouchi, A., Sakaguchi, Y., \& Niihata, S. (2011). Effects of load and gradient on energy cost of running. Journal of Physiology and Anthropology, 30(4), 153-160.

Assumpção, C. O., Lima, L. C. R., Oliveira, F. B. D., Greco, C. C., \& Denadai, B. S. (2013). Exercise-induced muscle damage and running economy in humans. Scientific World Journal, 2013, 1-11. doi: 10.1155/2013/189149

Borg, G. A. (1982). Psychophysical bases of perceived exertion. Medicine and Science in Sports and Exercise, 14(5), 377381.

Braun, W. A. \& Dutto, D. J. (2003). The effects of a single bout of downhill running and ensuing delayed onset of muscle soreness on running economy performed $48 \mathrm{~h}$ later. European Journal of Applied Physiology, 90(1-2), 29-34. doi: 10.1007/s00421003-0857-8

Brenner, I. K. M., Natale, V. M., Vasiliou, A. I., Moldoveanu, A. I., Shek, P. N., \& Shephard, R. J. (1999). Impact of three different types of exercise on components of the inflammatory response. European Journal of Applied Physiology, 80, 452-460.

Byrnes, W. C., Clarkson, P. M., White, J. S., Hsieh, S. S., Frykman, P. N., \& Maughan, R. J. (1985). Delayed onset muscle soreness following repeated bouts of downhill running. Journal of Applied Physiology, 59(3), 710-715.

Chen, T. C., Nosaka, K., \& Tu, J. H. (2007). Changes in running economy following downhill running. Journal of Sports Sciences, 25(1), 55-63. doi: 10.1080/02640410600718228

Chen, T.C., Nosaka, K., Lin, M. J., Chen, H. L., \& Wu, C. J. (2009). Changes in running economy at different intensities following downhill running. Journal of Sports Sciences, 27(11), 11371144. doi: 10.1080/02640410903062027

Chen, T. C., Lin, K. Y., Chen, H. L., Lin, M. J., \& Nosaka, K. (2011). Comparison in eccentric exercise-induced muscle damage among four limb muscles. European Journal of Applied Physiology, 111(2), 211-223. doi: 10.1007/s00421-0101648-7

Chen, T. C., Chen, H. L., Lin, M. J., Chen, C. H., Pearce, A. J., \& Nosaka, K. (2013). Effect of two maximal isometric contractions on eccentric exercise-induced muscle damage of the elbow flexors. European Journal of Applied Physiology, ahead of print.

Clarkson, P. M. \& Hubal, M. J. (2002). Exercise-induced muscle damage in humans. American Journal of Physical Medicine \& Rehabilitation, 81(Suppl), S52-S69.

Entin, P. L., Gest, C., Trancik, S., \& Coast, J. R. (2010). Fuel oxidation in relation to walking speed: influence of gradient and external load. European Journal of Applied Physiology, 110, 515-521. doi: 10.1007/s00421-010-1523-6.

Farr, T., Nottle, C., Nosaka, K., \& Sacco, P. (2002). The effects of therapeutic massage on delayed onset muscle soreness and muscle function following downhill walking. Journal of Science 
and Medicine in Sport, 5(4), 297-306.

Foschini, D., Prestes, J., \& Charro, M. A. (2007). Relação entre exercício físico, dano muscular e dor muscular de início tardio. Revista Brasileira de Cineantropometria e Desempenho Humano, 9(11), 101-106.

Gault, M. L., Clements, R. E., \& Willems, M. E. (2012). Functional mobility of older adults after concentric and eccentric endurance exercise. European Journal of Applied Physiology, 112(11), 3699-3707. doi: 10.1007/s00421-012-2338-4

Holm, J. K., Contakos, J., Lee, S. W., \& Jang, J. (2010). Energetics and passive dynamics of the ankle in downhill walking. Journal of Applied Biomechanics, 26(4), 379-389.

Hunter, L. C., Hendrix, E. C., \& Dean, J. C. (2010). The cost of walking downhill: is the preferred gait energetically optimal? Journal of Biomechanics, 43(10), 1910-1915. doi: 10.1016/ j.jbiomech.2010.03.030

Jamurtas, A. Z., Theocharis, V., Tofas, T., Tsiokanos, A., Yfanti, C., Koutedakis, Y., \& Nosaka, K. (2005). Comparison between leg and arm eccentric exercises of the same relative intensity on indices of muscle damage. European Journal of Applied Physiology, 95(2-3), 179-185. doi:10.1007/s00421-005-1345-0

Kamandulis, S., Skuvyrdas, A., Snieckus, A., Masiulis, N., Aagaard, P., Dargeviciute, G., \& Barazatis, M. (2011). Monitoring markers of muscle damage during a 3 week periodized drop-jump exercise programme. Journal of Sports Sciences, 29(4), 354-353. doi: 10.1080/02640414.2010.530676

Lima, L. C. R. \& Denadai, B. S. (2011). The repeated bout effect: a comparison between upper and lower limbs. Motriz, 17(4), 738-747. doi: 10.1590/S1980-65742011000400019

Lindstedt, S. L., LaStayo, P. C., \& Reich, T. E. (2001). When active muscles lengthen: properties and consequences of eccentric contractions. News in Physiological Sciences, 16, 256-61.

McHugh, M. P. (2003). Recent advances in the understanding of the repeated bout effect: the protective effect against muscle damage from a single bout of eccentric exercise. Scandinavian Journal of Medicine \& Science in Sports, 13, 88-97.

Minetti, A. E., Moia, C., Roi, G. S., Susta, D., \& Ferretti, G. (2002). Energy cost of walking and running at extreme uphill and downhill slopes. Journal of Applied Physiology, 93(3), 10391046. doi:10.1152/japplphysiol.01177.2001

Nosaka, K., Newton, M., \& Sacco, P. (2002). Muscle damage and soreness after endurance exercise of the elbow flexors. Medicine and Science in Sports and Exercise, 34(6), 920927.

Nosaka, K., Newton, M., Sacco, P., Chapman, D., \& Lavender, A. (2005). Partial protection against muscle damage by eccentric actions at short muscle lengths. Medicine and Science in Sports and Exercise, 37(5), 746-753. doi: 10.1249/01.MSS.0000162691. 66162.00

Nottle, C. \& Nosaka, K. (2005). The magnitude of muscle damage induced by downhill backward walking. Journal of Science and Medicine in Sport, 8(3), 264-273.

Saka, T., Akova, B., Yazici, Z., Sekir, U., Gür, H., \& Ozarda, Y. (2009). Difference in the magnitude of muscle damage between elbow flexors and knee extensors eccentric exercises. Journal of Science and Medicine in Sport, 8, 107-115.

Westerlind, K. C., Byrnes, W. C., \& Mazzeo, R. S. (1992). A comparison of the oxygen drift in downhill vs. level running. Journal of Applied Physiology, 72(2), 796-800.

Yang, Y. R., Lee, Y. Y., Cheng, S. J., \& Wang, R. Y. (2010). Downhill walking training in individuals with Parkinson's disease: a randomized controlled trial. American Journal of Physical Medicine \& Rehabilitation, 89(9), 706-714. doi: 10.1097/ PHM.0b013e3181e721c5
Yu, J. G., Malm, C., \& Thornell, L. E. (2002). Eccentric contractions leading to DOMS do not cause loss of desmin nor fibre necrosis in human muscle. Histochemistry and Cell Biology, 118, 2934. doi: 10.1007/s00418-002-0423-1

\section{Authors' note}

Leonardo Coelho Rabello de Lima, Felipe Bruno Dias de Oliveira, Claudio de Oliveira Assumpção, Camila Coelho Greco and Benedito Sérgio Denadai are with the Human Performance Laboratory, Physical Education Department, São Paulo State University, Rio Claro, SP, Brazil.

Thiago Pires de Oliveira is with the Human Performance Laboratory, Physical Education Department, São Paulo State University, Rio Claro, SP, and with the Anhanguera University Center, Leme, SP, Brazil

\section{Acknowledgments}

The authors would like to thank Coordenação de Aperfeiçoamento de Pessoal de Nível Superior (CAPES) and Conselho Nacional de Desenvolvimento Científico e Tecnológico (CNPq) for the financial support.

\section{Correspondence to:}

Leonardo Coelho Rabello de Lima Avenue 24-A, 1515, Rio Claro, SP 13506-900

Phone: (55-19) 9668-5358

E-mail: leonardocrlima@gmail.com.

Manuscript received on March 28, 2013

Manuscript accepted on June 22, 2013

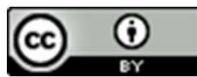

Motriz. Journal of Physical Education. UNESP, Rio Claro, SP, Brazil, eISSN: 1980-6574, is licenced under a Creative Commons License, Version 3.0. 